\title{
The Impact of Sport on Community Development in Greater August Town, Jamaica
}

\author{
By Olivene Burke* \\ Tarik Weekes ${ }^{\dagger}$ \\ Wanda Costen ${ }^{*}$
}

\begin{abstract}
Jamaica has long used sports as a tool for encouraging harmony amongst its citizens. Both the state and conflict prevention practitioners have used competitive and recreational sports as an avenue to resolve conflict between warring groups, and help group members learn more about each other. In some communities, playing a sport has provided people the opportunity to cross turf and borders, share community spaces, and create opportunities for dialogue between groups. The community of Greater August Town (GAT), located in St. Andrew, Kingston, Jamaica, is an example of such a community. This paper explores insight from phenomenological research probing how football as a sport impacts development in a community.
\end{abstract}

\section{Introduction}

Part of the motivation for pursuing this research has to do with understanding the contribution football has made to develop a sense of community and infrastructure to the benefit of residents in Greater August Town (GAT). For several years the community has been torn by collective forms of violence brought on by political elections. The resulting fragmentation between the residents is usual because of the deep ties they hold with rivalling political parties. There are five districts in GAT and across these districts are several corners. A 'corner' is a social and geographical space that can have a group identity. Charles (2004) explains that;

"The various 'corners' are allied to rival political parties under the leadership of the area don". A corner can be a yard, a street corner, a lane, part of a road, a street or part of a community." (p.31). A "don" is a community leader of questionable character.

\footnotetext{
${ }^{*}$ Executive Director/Lecturer, University of the West Indies, Jamaica.

${ }^{\dagger}$ Research Assistant, University of the West Indies, Jamaica.

${ }^{\star}$ Associate Professor, University of Tennessee-Knoxville, USA.
} 
Box 1. Names of Corners in Greater August Town

\begin{tabular}{|lcc|}
\hline Manley Avenue & Jungle 12 & Capitol Hill \\
April Way & & \\
Deuce Land & Open Land & May Lane \\
Bryce Hill & Church Yard & Cool \\
Runnings & & \\
Nineteenth Lane & Griz Close & Vietnam \\
Colour Red (o/c Judgement Yard) & June Road & Africa \\
Gardens & & \\
\hline
\end{tabular}

Source: Charles (2004)

The 'corners' are political strongholds that political parties have across the country. These strongholds are called 'garrisons' and reflect a clientelistic relationship between politicians, political parties and the marginalized communities. (Sives 2010). Not all districts and corners within them are politically motivated, but violence erupting from claims to turf or an area to secure votes for a political party, affects the entire community. For example, one particular corner has been known to cross over into other districts and corners and bully residents into voting for their allied political party ${ }^{1}$. The research questions guiding the study asked; how has the playing of football in GAT resulted in community development and what values in football are associated with community development? These questions allowed the researchers to delve into the interaction of macro and micro issues that surround the playing of football in the community, the residents and community development.

The objectives of the paper are to present a) findings from shared, lived experience of residents and b) highlight the contribution football made to develop the community.

\section{Theoretical Frameworks}

General systems theory (structure), social learning, self efficacy and collective efficacy (interpretive, constructivist) were suitable for the framing of a wider understanding of the contribution of sport globally, to developing people, communities and countries. The theories were useful to a point, because researchers were cautious of the potential bias they could have caused to the development of the research questions, the interrogation of participants and the interpretation of the data. This is very important to the philosophy of qualitative inquiry and phenomenology which value collecting rich experiences of participants and procedures that do not pre-conceive categories and themes of information. These should come from the data. (Glaser \& Strauss1967 cited in Creswell 2008). At the same time, the sampled theories helped with disconfirming information that may be accepted as universally associated with the impact of football and sport on people and communities.

\footnotetext{
${ }^{1}$ Personal correspondence [INT 1].Also corroborated by Charles (2004)
} 


\section{General Systems Theory (GST)}

Originated from ideas of Ludwig von Bertalannfy (1968), GST recognizes that society can be a system and within that system are subsystems and even more micro subsystems. For instance, it is possible to view GAT as a system, and a household within it as a subsystem. Generally, systems can be open or closed and it is likely that each system will have its own boundary. (Tamas 2000). A closed system is completely sealed off from its environment but nearly all organic systems are open, to allow for some form of energy or influence. A lot of this energy or influence can be in the form of communication which can create a very open system and encourage, sharing and harmony amongst persons. Infrastructure such as roads can also facilitate an open system. Alternatively, elements of mistrust or lack of trust can close a system. (ibid).

A community and society can be seen as a system and in that system, the real focus is on the whole and not the individual element. In, this interpretation of GST, one element by itself cannot make the system function, therefore taking each element and applying a mechanistic approach as opposed to an organic one will not bring success to the goal been pursued. In applying GST to GAT community and the study of human beings, there must be an acceptance of both, as organisms and living elements. (Tamas 2000). One of the strengths of GST is that it allows space for the environment to be considered as a factor and does not exclude other variables because of a mechanistic, focused attention on just one element. Spruill (2001) argues that "GST views the world as a series of nested systems to be understood in context rather than taken apart." Systems thinking reinforces the need to focus on interrelationships "rather than linear cause and effect chains and considering processes of change rather than snap shot events". (ibid)

\section{Social Learning Theory, Self Efficacy and Collective Efficacy}

Social learning is the notion of individuals learning behaviours that are acceptable or unacceptable by observing and imitating others (Fallon and Butterfield 2012). Imitation is described as the function of a successful model and process and individuals are able to learn from that. Social learning has progressed into social cognitive theory, of which theories of self efficacy and collective efficacy are off-shoots. Self efficacy is described as the level of confidence that an individual has in his or her ability to execute a course of action or attain specific performance outcomes. (Roos, Potgieter \& Temane 2013). This assertion of confidence has been proven to affect human functioning in a number of ways. For instance it has been suggested that high self efficacy is linked to high self esteem, better physical condition and greater well-being amongst other human qualities. On the other hand the term collective efficacy has been used to determine motivational beliefs in groups rather than in individuals. Bandura (1997) suggests that collective efficacy may be defined as the shared beliefs in the conjoint capabilities to execute courses of action required to achieve designated goals. He identified four ways of gauging efficacy. Of particular interest to this study is what he calls 'vicarious 
experiences' which concerns the comparison people draw between their level of competency and that of others who they perceive as similar. Seeing someone whom they perceive as similar succeed, can increase their efficacy

\section{Structuration Theory}

Structuration theory has not being included in much discourse on the impact of football on people and society (Dixon 2011). However its inclusion can represent a new way of thinking about the contradictory natural relationship between structure and agency in society. In structuration theory, neither agency nor structure exerts primacy over each other. Social systems are reproduced from social practices which are existent through time and space because they are adhered to by the majority of society's members (Sadan 1997, Dixon 2011). Rules and resources reproduce social action within the system. Giddens argues that although rules provide a formula for action it is resources that bring them to life.

\section{Methods}

\section{Social Context}

Research to understand the shared lived experience of playing football by residents of GAT was done in the community over a four month period. Table 1 provides key features of the community identified from to local development agencies and the pro-longed engagement of two research team members. A multi-modal approached was used that was supported by the immersion of the researchers into the community. This augured well for opportunities to validate information and triangulate data. The data was collected through qualitative inquiry accompanied by ${ }^{1}$ participatory learning and action (PLA) techniques.

Table 1. Key Community Features in Community-Wide Data Collection

\begin{tabular}{|c|c|c|}
\hline $\begin{array}{l}\text { Group A- } 2 \text { Community } \\
\text { districts } \\
\text { - Unemployment } \\
\text { - Incidence of reported } \\
\text { \& violence } \\
\text { - Known presence of } \\
\text { gang activities. } \\
\text { - Low levels of } \\
\text { education (reached } \\
\text { high school) } \\
\text { - Poor housing stock } \\
\text { - One recreation area } \\
\text { - Small shops adjacent } \\
\text { to homes }\end{array}$ & \begin{tabular}{ll} 
& \multicolumn{1}{c}{ Group B-3 } \\
- & Unmemunity districts \\
- & Incidence of reported \\
and violence \\
- & Medium levels of \\
education ( completed \\
high school) \\
- Known presence of \\
gang activities \\
- Good housing stock \\
(concrete walls, zinc \\
roof, medium sized \\
homes)
\end{tabular} & $\begin{array}{l}\text { Group C- } 1 \text { Community } \\
\text { district } \\
\text { - Unemployment } \\
\text { - No incidence of } \\
\text { collective violence } \\
\text { relative to A,B \&G. } \\
\text { - Completed high } \\
\text { school and reached } \\
\text { tertiary level. } \\
\text { - Unknown presence of } \\
\text { gang activities } \\
\text { - One or more } \\
\text { recreational } \\
\text { facilities/areas. } \\
\text { - }\end{array}$ \\
\hline
\end{tabular}

${ }^{1}$ Participatory Learning and Action is a tool used to collect and analyze data. It is a family of approaches that allow people to plan, empower and to act. (Absalom 1995) 
- None to minimal street lighting

- Greater presence of dirt tracks than primary road.
- At least one recreational facility/area

- A community meeting place

- At least one community group

- A number churches

- A minimal street lighting

\section{Training of Field Staff}

Ten individuals who formed part of the field staff for data collection were trained. This knowledge sharing activity was important to the proper interpretation of the questions in the question guide, learning skills related to proposing questions to participants and understanding the use of PLA techniques in group settings.

Among the participants were two community persons (females), who served as liaisons between the community and the research group (See Table 2). Including them would provide greater buy-in from the community and less aversion from the residents to answering questions. The other benefit to the inclusion for the data collection were:

- Customization of questions in terms of language and appropriateness

- Knowledge of community corners

- Knowledge to assist with purposeful interviewing whilst in the community

Table 2. Gender Breakdown of Participants/ Research Group

\begin{tabular}{|c|c|}
\hline Male & 4 \\
\hline Female & 6 \\
\hline
\end{tabular}

Pre-interviewing of two known community residents provided an opportunity to snowball, purposefully sample for interviewees and also further develop the question schedule.

\section{Interviews and Focus Groups}

Eight, forty minute - one hour in-depth interviews were conducted between November and December 2014 (See Table 3). Every participant received a consent form which they signed, anda question schedule, prior to the interview. Allowing the interviewees to familiarize themselves with the questions before hand strengthened their confidence in the contribution they could make. It helped with accuracy as respondents had a chance to validate even with others what they would be saying in the interview. In-depth interviews used, require participants to be comfortable in the interview. Dilley (2000) notes how important this is for reflection by the interviewees and the possibility of retrieving "extensive and multiple answers". 
Member checking was also employed at the close of the interviews to give interviewees the opportunity to confirm information or accounts of experiences provided. According to Creswell and Miller (2000), member checking is a validity procedure that shifts from the researcher to the participant. It consists of taking the data and interpretation back to the participants in the study so they can confirm credibility.

A panel of University lecturers, who are also experts on qualitative research, audited the question schedule to ensure their ability to capture the data needed. This type of review formed an auditing procedure that is also recognized as an approach to securing validity in a study. (ibid). In all the interviews participants were encouraged to talk freely which supported techniques for questioning such as storytelling and timelines.. This was also encouraged in the community-wide data collection interviews

Table 3. Breakdown of Interviewees by Type of Affiliation

\begin{tabular}{|c|c|c|}
\hline No. & Sex & Organization Type \\
\hline 2 & Female & Government Agency \\
\hline 1 & Male & Law enforcement \\
\hline 1 & Female & Educational Institution \\
\hline 2 & Male & Community based organization \\
\hline 2 & Male & Independent \\
\hline
\end{tabular}

Two focus groups with 11 young males between 13-16 years old, who play for the GAT under-17 football team, were held in March 2014 (See table 4). The focus groups served a dual purpose. These one-hour long sessions probed the origins of the youths' involvement in sport against the mannerisms needed for the sport and its transference into their lives. The researchers got a chance to reflect on some of the questions that could be asked in a questionnaire, administered to the same males at a later stage, to understand the personal development outcomes they experienced since being part of the football team. Inglis (1992) recognizes that focus groups can be useful in generation of an understanding of terminologies that can help with question design for a questionnaire. While Jamaica is recognized as a football and track nation, very little research has been done on the impact of sport overall, let alone football. The focus groups allowed the researchers to understand the meaning behind playing football for the young players and helped validate the context of playing football in the community.

Table 4. Age Range of Male Participants in Two Focus Groups

\begin{tabular}{cc} 
Ages (yrs) & Frequency \\
$13(2001)$ & 1 \\
$14(2000)$ & 1 \\
$15(1999)$ & 1 \\
$16(1998)$ & 2 \\
$17(1997)$ & 9 \\
$18(1996)$ & 1 \\
\hline
\end{tabular}




\section{Community Wide Data Collection}

Using storytelling techniques, the residents were asked to describe the playing of football in their community. They were also asked to list and describe what contribution the playing of football has made to community development. Responses were documented through note-taking and drawings on paper.

\section{Data Analysis}

The playing of football was placed into three categories to help with the micro analysis of the research questions. The structured group involved players, coaches, referees, and team assistants who follow a competition driven programme. ${ }^{1}$ The unstructured group includes football enthusiasts who are not part of a club, group or organization and may play recreational football. A third group comprised persons who are part of loosely organized teams that participate in corner league football. It is not uncommon for a player who is part of the semi structured playing of football to be part of the unstructured group.

The open coding of the data yielded several possible core categories linked to the research questions identified for this study. These core categories have emerged based on the frequency of the codes by themselves in the data and also as co-occurrences when analyzed using the Atlas-ti software. For example one of the core categories has been "sports used as a method of building community", which was applied where participants spoke to sports being used to foster community cohesion. More than 30 co-occurrences were found. A cooccurrence can be described as a set of things that occur at the same time or place. (Le Compte 2000).Using Atlas-ti, it was also identified that individual elements supporting a code could have been reinforced across various interviewees, strengthening co-occurrence. Table 5, gives a breakdown of some comments relating to how sport was used to build community. Other core themes that emerged from the open coding were 'unity' and 'community'.

Table 5. Taxonomy for Sports as a Method for building Community

\begin{tabular}{ll} 
Taxonomy Name (Y) & \multicolumn{1}{c}{ Items (X) } \\
& - No violence happens when sports is being played in \\
the community \\
- People free to walk across boundaries \\
- Police and youth play football together and police \\
Sports as a method for & establish rapport with youth \\
building community & - People from all age groups at corner league matches \\
& - Being part of football in the community is being on \\
& common ground \\
- League pride people showing support for the \\
football team regardless of district
\end{tabular}

${ }^{1}$ Personal correspondence (memo) field observation exercise 


\section{Discussion \& Issues}

\section{Sports as a Method of Building Community}

There are several country and situation examples that highlight strong relationships between the playing of football and people's interpretation of themselves and others and the thrust towards social change. Bob, Knott and Swart (2011) speak of the social benefits that sport brought to post apartheid South Africa, breaking down divides between people because of racial barriers and providing a space for reconciliation. In one broad sense, football as a game can be inclusive and exclusive and in another broad sense can be a space for the exercise of agency by individuals towards a movement for social change. Levermore (2008) cited in Bob, Knott and Swart suggests that sport can be used to foster social cohesion and tackle elements of exclusion such as poverty, youth and gender.

Since the early 1970s, the community has been involved in hosting corner league football (soccer) matches, which have united the community. ${ }^{1}$ Then, corner league football was organized by one person who saw the need to bring together residents of the community. The playing of football in these early days was a reinterpretation of the football played by the more elite in society. A tennis ball was used by the residents to play on the roads or wherever suitable. The playing of the corner matches helped form new perceptions about individuals living in the community and created a sense of togetherness amongst persons. While the games brought persons together it also experienced bouts of violence with people fighting after matches. In the community-wide data collection, residents suggested that "football cause the violence too" in the community and that sometime people "carry feelings" and "grudges" and come to the football matches to "settle things".

"Football is not bad for the community, it is good. It brings about love and peace and helps you to carry on your work. It can sometimes be a source of conflict: 'him nuh like dat person'.,"3

The playing of football in the community at the corner league and team level conjures feelings of social connectedness between residents regardless of each having different systems of organization. In one of the visits to a corner league match within one of the districts, people from all age groups were seen eagerly watching the games while some children were also seen playing the sport in nearby lanes. This togetherness demonstrates collectivity and inclusion that is important to organization and representation for a community such as GAT. People walking freely across boundaries whenever there are corner league matches occurring, gives relatives an opportunity to see persons not seen due to violence. The playing of football also allowed for reconciliation between persons.

"As I said before, there are persons in the community who have had relatives killed by other persons, way back dating as far as 1980 . Sometimes

\footnotetext{
${ }^{1}$ Personal correspondence (INT 5)

${ }^{2}$ Interview from community wide data collection [CWI 2]

${ }^{3}$ Personal correspondence [INT 2]
} 
persons keep feelings. Now we have restorative justice coming in but before that there was football and unless there is a common meeting ground, where persons can see each other, feelings start to go. .... But once we are on the playing field, we play together, seeing the person more regularly, the thirst for revenge is no longer there. There have even been times where persons have spoken and some informal peace treaty is signed because man really gets a chance to talk to another man."1

Table 6. Characteristics of Playing Football in Greater August Town

\begin{tabular}{|c|c|c|}
\hline $\begin{array}{c}\text { Structured Playing of } \\
\text { Football }\end{array}$ & $\begin{array}{l}\text { Unstructured } \\
\text { (Recreational) }\end{array}$ & $\begin{array}{l}\text { Semi- Structured } \\
\text { (Corner League) }\end{array}$ \\
\hline $\begin{array}{l}\text { Presence of a coach } \\
\text { - Registration and } \\
\text { membership structure } \\
\text { Regular Training } \\
\text { (daily, weekly) } \\
\text { towards competition } \\
\text { - Advanced training } \\
\text { more performance } \\
\text { oriented } \\
\text { - Heavy emphasis } \\
\text { placed on winning. } \\
\text { Incentivized through } \\
\text { rewards } \\
\text { Training takes place } \\
\text { on/in a standard } \\
\text { facility } \\
\text { Formal assignments of } \\
\text { task and roles. }\end{array}$ & $\begin{array}{l}\text { - } \quad \text { "kick up ball" } \\
\text { - No presence of a } \\
\text { coach } \\
\text { - No standard facility } \\
\text { for playing } \\
\text { - Emphasis on winning } \\
\text { - Informal assignment } \\
\text { of roles }\end{array}$ & $\begin{array}{l}\text { - Barely existent and } \\
\text { below par standard } \\
\text { facilities } \\
\text { - } \begin{array}{l}\text { Incentivized through } \\
\text { rewards }\end{array} \\
\text { - } \begin{array}{l}\text { Corner, community } \\
\text { oriented }\end{array} \\
\text { - Small scale } \\
\text { competitions } \\
\text { - Smaller teams (six a } \\
\text { side) }\end{array}$ \\
\hline
\end{tabular}

The playing of football at the corner league level can be regarded as a subsystem within a wider interpretation of playing football in GAT. Participation can come from within or outside GAT. Again, this reinforces certain patterns of behaviour and community practices. . At an early age, youth engage the playing of football because they heard of or saw a family member playing football ${ }^{2}$. The young males who participated in the focus group know of grand fathers or uncles, or their mothers tell them of their family history with football, and identify these as pull factors for playing the sport.

\section{Community}

The issue of community also emerged from the data. Majority of residents spoke about the playing of football within their particular district. Other times when playing of football was mentioned it involved complaints about the membership of the August Town Football team or to identify with it as their own. Those complaining felt that the team should comprise more players from

\footnotetext{
${ }^{1}$ Personal correspondence[INT 2]

${ }^{2}$ Focus group correspondence [ FG 1]
} 
the community. At the time of the research only two players on the senior team were from the community. This experience is not uncommon amongst football teams globally who have players foreign to teams playing on them. Residents perceived the team membership as troubling because it is important for them to see the team as their own. This makes sense based on conversations researchers had with other interviewees very close to the organization of the football team. "One of the things I have come to realise over the years, is that people will tend to identify with their own"1 one interviewee said. He was referring to the experience of persons following the team wherever they went to play matches outside of Kingston. In 2006, the August Town football team earned the opportunity to play in the Premier League playoffs. This was a major accomplishment that generated community pride for the residents. This sentiment overlapped with energies for the unifying of the districts and residents.

Despite the years of playing football in the community, there is an absence of standard facilities to play the game. There is also the added dimension of the challenges organizers of the corner league face with financing football. In one district, a group of men and women reasoned that the playing of football in the area was hampered by the ability to gain sponsorship.(See Figure 1) They highlighted lack of 'links' (networks), and no experience as root causes to the sponsorship challenge. Positive outcomes they indicated is sponsorship to allow corner league football to play in the community. Amongst these included no criminal violence.

Each district has a playing field, but these are usually not maintained and lack the infrastructure to cater to players and spectators. One district, with the help of the nearby University of the West Indies, (UWI) Mona campus was able to convert an abandoned industrial zinc-space into a concrete multipurpose playing area.(See Figure 2) Even there, lighting, inadequate seating and other amenities for the comfort of the spectators are absent. It is for reasons like these that the relationship between the community and the UWI campus is important. Players on the August Town team are able to use the facilities there, such as the gym and pool for their performance training. The community has committed to maintaining this decades long relationship with the University, and have earned the right to use a field at the Campus, as their "home-field". A home-field was necessary for the community football team to enter Major League competition, which is the lowest level of competition (followed by Super League and Premier League playoffs ${ }^{2}$ ).

\footnotetext{
${ }^{1}$ Personal correspondence[INT 1]

${ }^{2}$ Similar to the NFL, a team advances from Major to Super to the Premier league playoffs by winning at each stage.
} 
Figure 1. Problem Tree with Sponsorship as a Problem

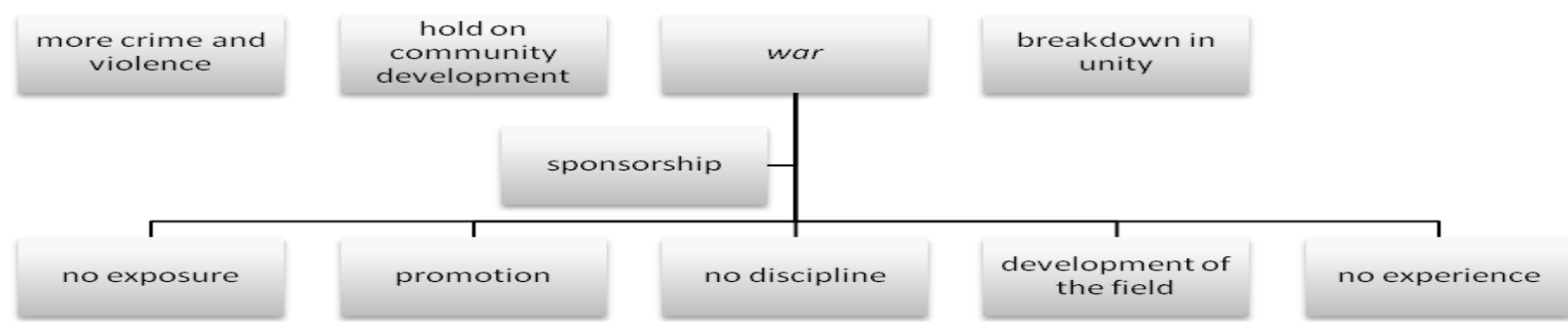

Figure 2. Playing Football at a Corner League Venue

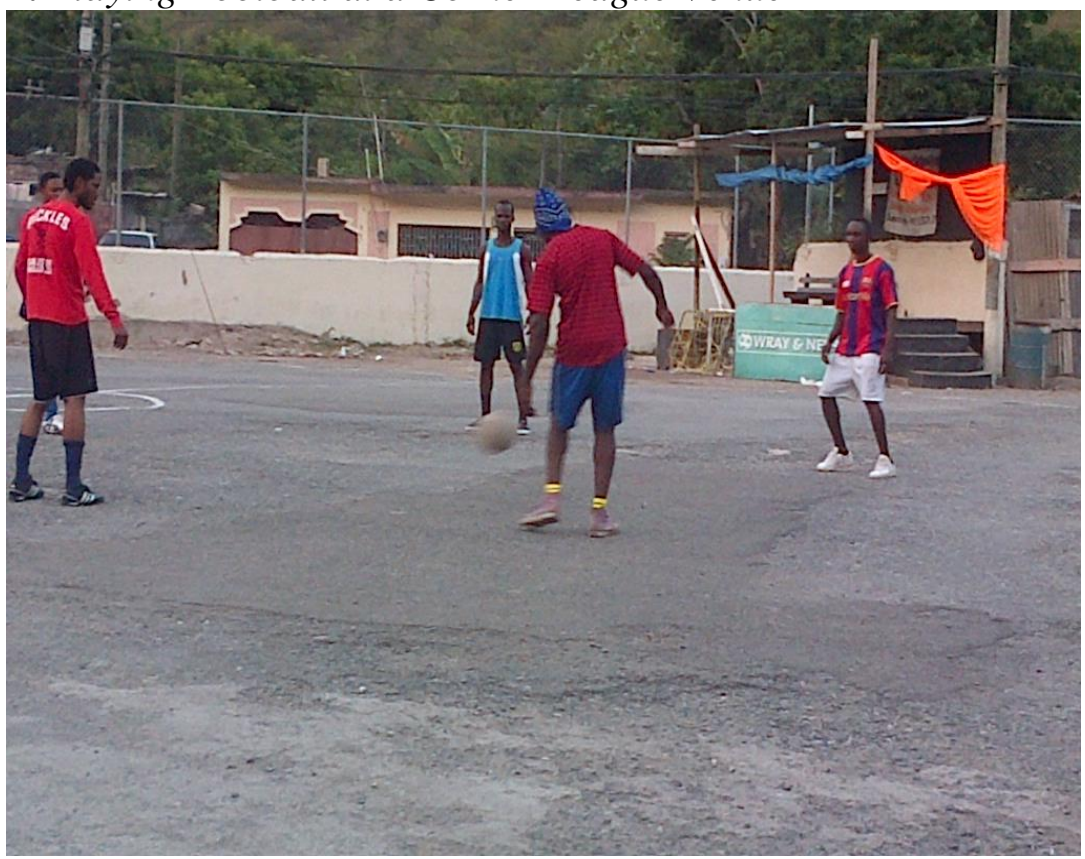

A closer examination of the themes mentioned identifies critical issues regarding the playing of football in the community and the contribution to its development. First, the playing of football brings people together at a local level and around the rallying of their national football team. This has been exemplified through the attendance of matches where football is played. If football is being played, there must be some level of organization but there has been little change socially and economically for the community. Several organizations led by individuals from the community arrange playing of football but they do not all work together for other community development purposes. This is indicative of a disconnection and contradiction regarding how people view the value of their actions in the eyes of others and further to this, the partisan political residue bearing division and opposed to inclusion.

Linked to the above issues is also the element of what we have seen in the textural description as "common ground" and "goals". The playing of football has many patterns of behavior that have become custom in the community and 
reinforced through practice. The community is still very much disadvantaged where resources are concerned and there has to be transference between the positive values stimulated through the playing of football into collective action. The playing of football can be seen as a metaphor for collective action. Each player, regardless of his skills level has a role to play on a team focused on goals. This requires each player to be confident in their contribution, exercise trust and reliance in others for a perceived common good. The playing of the sport falls within a structure with rules and sanctions but what is foremost is that each player can exercise a degree of agency and represent themselves. This metaphor of playing football was evident in the two focus groups discussions where the goals for the young men extended beyond scoring and winning as a team. For example scoring a goal meant well for the team and feelings of membership. Membership is equated with working hard and being disciplined towards gaining scholarships for education and personal mobility. Below is an extract of a conversation with young males on the community's junior football team, probing their playing of football.

- $1^{\text {st }}$ response: "foot ball is like a ticket to a free scholarship to avoid tuition"

- $2^{\text {nd }}$ response: “football is like a job, once you are getting paid. If you are going to get paid in life you are going to have to play hard".

- $\quad 3^{\text {rd }}$ response: "when you are doing a job, you have a time schedule. So if the boss tells you a time you have to reach that time, so when coach tells you a time you have to be there."

\section{Conclusion}

There is a lot more to be explored regarding the personal development outcomes of football and the transference and impact it is having on the Greater August Town community. This is something that the researchers will be exploring further. Playing football in the community is definitely part of a shared lived experience of residents and this experience has brought solutions to some of the problems the community is facing in terms of developing. There is still a lot more to be done regarding breaking down the normative behaviour of collectivism that is apparent only when the game is being played and moving it beyond that space through self reflection to collective action. There is little impact by way of social and economic change. It is recommended that the playing of football at the corner league level be examined more closely, be treated as a community development project and provided with the necessary injection of finances to bring about better structure and revenue to the community and its residents. 


\section{References}

Absalom, Elkanah, Chambers Robert et al, 1995. Sharing our concerns and looking to the future, PLA Notes, International Institute for Environment and Development.

Alanezi, Fawaz, 2007. Structuration Theory: A Third Perspective. Journal of the Social Sciences, Vol.35 No.2 p.37-43, Kuwait University.

Bandura, Albert, 1997. Self Efficacy: The exercise of control, New York. Freeman

Bob, Urmilla, Knott Brendon, Swart Kamilla et al 2011, A sport and socio-cultural Legacy beyond 2010: A case study of the football foundation of South Africa, Development Southern Africa, Vol.28,No.3, Routledge, Taylor andFrancis Group

Charles, C.A.D. 2002. Garrison communities as counter societies: The case of the 1998 Zeek's riot in Jamaica. I. Boxill (Ed.), IDEAZ (Vol. 1, pp. 29-43). Kingston: Caribbean Research Institute.

2004. Political identity and criminal violence in jamaica: The garrison community of August Town and the 2002 election. In Social and Economic Studies (2 ed., Vol. 53, pp. 31-73). Kingston: Sir Arthur Lewis Institute of Social and Economic Studies.

Contemporary Justice Review Vol. 13, No. 4, December 2010, 355-369, Routledge. DOI: $10.1080 / 10282580.2010 .517960$

Creswell John, Miller Daniel 2000. Determining Validity in Qualitative Inquiry, Theory into Practice Vol.39 Issue 3 p. 124-130

Creswell, John. 2008 Educational Research $3{ }^{\text {rd }}$ Edition, New Jersey, Pearson/ Merrill Prentice Hall chp. 14 p.432-467

Dilley, Patrick 2000. Conducting Successful Interviews: Tips for Intrepid Research, Theory Into Practice Vol. 39 Issue, p 124-130

Dixon, Kevin, 2011. A third way for football fandom research: Anthony Giddens and Structuration Theory, Journal of Soccer and Society Vol. 12, No. 2. P. 279-298, Routledge

Fallon, Michael, Butterfield Kenneth. 2012. The Influence of Unethical Peer Behaviour on Observers' Unethical behaviour: A Social Cognitive Perspective, Journal of Business Ethics, Springer Science and Business Media. P. 119-122

Headley, B. (2002). A Spade is still a Spade: Essays on crime and the politics in Jamaica. (p. 100). Kingston: LMH Publishing Limited.

Inglis, Sue (1992) Focus Groups as Useful Qualitative Methodology in Sports Management, Journal of Sports Management, p. 173-178

Klassen Ann, Creswell John, 2012 Best practices in mix methods for quality of life research, Quality of Life Research Journal, chp. 21 p377-380

Levy, Horace. 2009. Inner city killing streets: Reviving community. (Arawak Monograph Series ed.). Kingston: Arawak Publications.

Lewis, Theodore, 2011. Assessing social identity and collective efficacy as theories of group motivation to work, International Journal of Human Resource Management Vol.22, No. 4 p963-974, Routledge.

Sadan, Elisheva, 1997.Developing a Theory of Empowerment, Empowerment and Community Planning, in Theory and Practice of People -Focused Social Solutions, Hameuchad Publishers, Tel Aviv

Sives, Amanda 2010. Elections Violence and the Democratic Process in Jamaica 1944-2007, Ian Randle Publishers, Kingston p. 52-77 
Vol. 1, No. $3 \quad$ Burke et al.: The Impact of Sport on Community Development...

Skinner, J., Zakus, D. H., \& Cowell, J. (2008). Development through Sport: Building Social Capital in Disadvantaged Communities. Sport Management Review, 11(3), 253-275.

Tamas, Andy, 2000. Systems Theory in Community Development, Whitehorse, Yukon and Almonte http://www.tamas.com/samples/source-docs/System_Theo ry_in_CD.pdf, Retrieved March 72014

Warner Barbara, Ohmer Mary, Beck Elizabeth, 2010 Linking informal social control and restorative justice: moving social disorganization theory beyond community policing. 